\title{
健常中高年女性における, 家庭で行う筋力トレーニングが 筋力・バランス・歩行に与える影響について
}

\author{
The Effects of Home Exercise on Muscle Strength, Physical Balance and Gait of \\ Community-Dwelling Elderly Women
}

\author{
山端るり子1） 兒田 滋2) 遠藤 文雄 ${ }^{2)}$ \\ RURIKo YAMAHATA, RPT ${ }^{1)}$, SHIGERU USUDA, RPT ${ }^{2)}$, FUMIO ENDO, RPT ${ }^{2)}$ \\ 1) Center of Rehabilitation, Hidaka Hospital, 886 Nakao-machi, Takasaki, Gunma 370-0001, Japan. TEL +81 27-362-6201 \\ 2) Gunma University School of Health Sciences
}

Rigakuryoho Kagaku 13(2): 89-94, 1998. Submitted Mar. 20, 1998. Accepted May 10, 1998.

\begin{abstract}
The purpose of this study was to examine the effects of home exercise on muscle strength, physical balance and gait of community-dwelling elderly women. The subjects consisted of a group of 12 healthy women (aged $68.0 \pm 4.1 \mathrm{yrs}$ ) performing 3 -month home exercise (training group), and a control group of 7 women (aged $69.0 \pm 3.7$ yrs). All subjects completed the tests, including knee extension and flexion strength, functional balance scale, functional reach, postural sway, maximal gait speed and 6 minutes distance, before and after exercise. The exercise, composed of 10 resistance exercises with free weight in sitting or standing, was performed at RPE 15 in 8 or 10 repetitions (1 set) per one exercise. Exercise protocol was 2 or 3 sets of 4 or 5 exercises a day, 2 or 3 days a week, over 3 months. The training group showed significant improvements in functional reach, maximal gait speed $(\mathrm{p}<0.01)$, functional balance scale results $(\mathrm{p}<0.05)$, and 6 minutes distance, but no change in muscle strength and postural sway. The control group exhibited an improvement in 6 minutes distance. The results revealed the effectiveness of the home exercise in improving functional balance and gait speed of community-dwelling elderly women.
\end{abstract}

Key words: home exercise, physical fitness, elderly

要旨：健常中高年女性における家庭で行う筋力トレーニングが, 膝屈伸筋力, バランス, 歩行能力に与える効果の検討 を本研究の目的とし, トレーニング群 12 名 $(68.6 \pm 4.1$ 歳）とコントロール群 7 名 $(69.0 \pm 3.7$ 歳）を分析対象とした。 筋力トレーニングは, 坐位や立位での重鍾バンドを用いた 10 項目の抗重力運動で構成され，運動強度は $8 \sim 10$ 回の反 復運動でRPE15，運動頻度は1 日4～5 項目を3セット，1 週間に2〜3日とし，3カ月間にわたり施行した。トレーニン グ前後において，トレーニング群では, 機能的バランス, $10 \mathrm{~m}$ 最大歩行速度, 6分間歩行距離が有意に向上し, 筋力と静 止立位時の重心動摇に変化はなかった。コントロール群では，6分間歩行距離のみに向上が認められた。本研究における 筋力トレーニングは, 健常中高年女性の機能的バランスと歩行速度の向上に効果があった。 キーワード：トレーニング, 体力, 中高年

1）日高病院リハビリテーションセンター：群馬県高崎市中尾町 886 （テ 370-0001）TEL 027-362-6201

2) 群馬大学医学部保健学科

受付日 1998 年3月20日 受理日 1998 年5月 10 日 


\section{I.はじめに}

高齢者が自立した生活を送るためには, 加齢に伴う能 力低下や機能障害を予防し, 身体活動能力を維持 - 増進 することが重要である1)。

加齢に伴う筋力低下について Frontera ら ${ }^{2)}$ は，上肢よ りも下肢の筋力低下の方が顕著であると報告している。 荒尾 ${ }^{1)}$ は, 歩行能力の低下は手腕や身辺の作業能力の低 下に先行して現れると述べている。また, Bendallら ${ }^{3)}$ は， 高齢者の歩行速度は, 年齢や下肢筋力などと強い相関関 係があると報告した。

高齢者の歩行速度の改善を目的としたトレーニング効 果についての研究で, Judge ら ${ }^{4)}$ は, 筋力増強訓練やスト レッチ, バランス訓練により, 筋力と歩行速度の改善を 報告した。また, Sauvageら ${ }^{5)}$ は, 施設に入所している 60 歳以上の男性を対象として, 筋力増強訓練と有酸素運動 を併用して行った。そして, 筋力, 歩行能力の改善を報 告した。これら2つの研究では, 運動機器を利用したり, 専門家の監視下でトレーニングが行われている。

高齢者の健康維持・増進のためのトレーニングは, 長 期間継続することが重要であり, 運動方法が簡便である こと, 実施場所が身近であること, 安全であることなど の要素が必要である1)。トレーニングを長期間継続する には, 簡便な運動を比較的中等度の負荷で, 家庭で安全 に行えるのが望ましいと考えられる。家庭でトレーニン グを行った研究は, Chandlerら6)が行っている。彼らの研 究では, 10 週間にわたる理学療法士の指導下で, 運動頻 度を 1 週間に 3 日間とし, ゴムバンドを用いた漸増抵抗 運動による筋力増強を認めている。そして, 筋力増強と 歩行速度や移動能力との間に有意な相関を報告した。し かし, 家庭で, 比較的中等度の負荷で行うトレーニング が, これまでの報告と同様に, 筋力, バランス能力, 歩行 能力の維持・改善に効果があるかは明らかではない。

本研究は, 家庭で行う筋力トレーニング(以下, トレー ニング)が, 膝屈伸筋力, バランス能力, 歩行能力に与え る効果を検討することを目的とし, 日常生活及び屋外歩 行の自立している地域の健常中高年女性を対象に, 家庭 で行うトレーニングを指導し，3カ月間施行した。

\section{II. 対 象}

地域に在住する, 60 歳以上の中高年者に体力測定の参 加を募集した。参加の条件は, 屋外歩行が自立しており, 日常生活に支障がないこととした。
体力測定に参加した女性50名のうち, 本研究の目的を 説明し，3カ月間のトレーニングの継続に同意した 12 名 をトレーニング群とした。また, トレーニングを行わな かった者のうち,トレーニング終了時期に体力測定に同 意した7名をコントロール群とした。

トレーニング群の平均年齢は $68.6 \pm 4.1$ 歳, コントロー ル群は $69.0 \pm 3.7$ 歳であった。

\section{III. 方 法}

\section{1. 体力測定}

身体所見として, 身長, 体重, 体脂肪率を測定した。体 脂肪率は, インピメーターSS110 (積水化学工業社製)を 使用し,インピーダンス法にて測定した。測定時は被験 者を椅子に座らせ, 上腕部は腋窩が密着しないように肘 を軽度伸展させ, 前腕部は左右の橈骨茎状突起が平行に なるように机の上に乗せた。

バランス能力は, Functional Balance Scale ${ }^{7,8)}$ (以下, FBS）と重心動摇を測定した。FBSは，立ち座りや閉眼立 位, 片脚立位など, 日常生活で必要な動作 14 項目それぞ れについて, 0 点 (要介助) $\sim 4$ 点 (自立), 合計 56 点で 得点化するように構成されている。このスケールは, 健 常高齢者の転倒との関連の研究 ${ }^{9}$ や, 片麻痖患者の移動 能力の研究 10)などにも使用されている。重心動摇は, 重 心動摇計 G6100（アニマ社製）を使用し, ロンベルグ足 位にて, 開眼と閉眼時の重心動摇距離（測定時間内の重 心点の移動した全長) と, 重心動摇面積 (前後, 左右方向 の重心動摇の最大振幅で囲まれる長方形の面積）を測定 した。サンプリング周期を $50 \mathrm{~Hz}$ ，サンプリング時間を $30 \mathrm{~s}$ とした。なお，開眼時は， 2 m離れた指標を注視するよう 指示した。

歩行能力は, $10 \mathrm{~m}$ 最大歩行速度 (以下, 最大歩行速度) と6 分間歩行距離（6 minutes distance：以下, 6MD）を測 定した。最大歩行速度の測定では, 歩行路 $15 \mathrm{~m}$ を「でき るだけ速く歩いて下さい」の指示で行い, 中央 $10 \mathrm{~m} に$ 要 した時間と歩数を測定した。そこから, 最大歩行速度 $(\mathrm{m} / \mathrm{s})$, 歩幅 $(\mathrm{m})$, 歩行率 $(\mathrm{step} / \mathrm{min})$ を算出した。6 $\mathrm{MD}$ の測定では, 同歩行路の両端に椅子を置き,「椅子と椅子 の間を八の字を描くように, 6 分間でできるだけ長い距 離を歩いて下さい」の指示で行い, 6分間の歩行距離を測 定した。

筋力は, サイベックス 770 (サイベックス社製) を使用 し, 左右の滕屈伸筋力を測定した。測定肢位は股関節 $90^{\circ}$ 屈曲位の坐位で, 体幹, 骨盤, 大腿遠位部を固定し, 上肢 は胸の前で組ませた。アンクルパッドは足背屈を妨げな 
いように固定した。角速度を $0 \cdot 60 \cdot 180 \mathrm{deg} / \mathrm{s}$ に設定し， 測定関節角度は, $0 \mathrm{deg} / \mathrm{s}$ では膝 $60^{\circ}$ 屈曲位, $60 \cdot 180 \mathrm{deg} /$ $\mathrm{s}$ では膝屈曲 $0 \sim 90^{\circ}$ とした。測定回数は, 3 角速度とも 3 回とし, $0 \mathrm{deg} / \mathrm{s}$ では, 膝伸展 · 屈曲を交互に 5 秒間の最 大収縮をさせ，各運動間に 10 秒間の休鄎を設けた。60・ $180 \mathrm{deg} / \mathrm{s}$ では, 膝伸展・屈曲を反復運動させた。なお， 3 角速度間には，60秒間の休憩を設けた。測定肢は，利き 足（通常ボールを蹴る側）に続いて反対側を行った。

体力測定は, トレーニング前と, トレーニングを開始 してから 1 カ月毎に行った。測定結果は, コメントを加 えたものを郵送にて返却した。

コントロール群の体力測定は, 第 1 回目から 3 カ月以 上経過してから再度行った。

\section{2. トレーニング}

トレーニング指導のために1日設け,「お年寄りのため の安全な筋力トレーニング」11)を参考に，内容と方法を 指導した。

トレーニング内容は, 上肢 3 項目の運動（坐位での肩 外転, 坐位での肘屈伸) と, 下肢7項目の運動（立位での 股屈伸·外転, 坐位での膝伸展, 立位での膝屈曲, 坐位で の足背屈，立位での足底屈）を, 重力に抗して行うょう に構成されている。これらについて，下肢の運動を中心 に指導した。トレーニングを安全に遂行するために, 負 荷は重錘バンドを使用し，手首や足首に巻いて落ちない ようにした。また，立位での運動では，椅子の背もたれ や壁を支えながら行うようにした。重錘バンドの負荷の 設定は, Borgの自覚的運動強度（以下，RPE）に準じた。 RPE は,「とても，とても軽い」から「とても，とてもつ らい」と感じる運動強度を 6〜20の尺度で構成したもの で, 自覚的運動強度を定量する方法である。この方法に 準じ，1項目の運動を8〜10回 (1セット) 行った時のRPE を約 15 とした。また，トレーニング実施期間中に負荷が 軽く感じるようになれば, 負荷を増加するように指導し た。運動方法は, 1 つ運動をゆっくりと行うこと, 呼吸 を止めないように行うことを指導した。運動頻度は, 基 本的に 1 日 $4 \sim 5$ 項目を左右について $3 セ ッ ト ， 1$ 週間に 2〜3日とした。また, 笳肉痛やその他の疼痛, トレーニン グの妨げとなる体調の時は，無理をしないよう指導した。

トレーニングの実施状況については, 1 カ月毎の体力 測定の際に簡単な自己申告をさせ，必要に応じて，トレー ニング内容や運動強度・頻度等を指導した。

\section{3. 分析}

トレーニング前の対象者の身体所見について, 各群の
平均值を算出し, $\mathrm{t}$ 検定にてトレーニング群とコント ロール群を比較した。

トレーニング効果については, 体重, 体脂肪率, 利き 足の膝屈伸筋力の体重比 (ピークトルク值 $(\mathrm{Nm}) /$ 体重 $(\mathrm{kg})$ $\times 100=\%$ body weight : 以下, $\% \mathrm{BW})$, 最大歩行速度, 歩 幅, 歩行率, 6MD, 重心動摇距離·面積, FBSの得点とし た。また, FBSの検查項目のうち, 利き腕を $90^{\circ}$ 前方挙上 して前へ伸ばせる最大距離をFucntional Reachとし, 身長 で補正した值 (Functional Reach $(\mathrm{cm}) /$ 身長 $(\mathrm{cm})$ : 以下, FR) についても分析した。

以上の項目について, 群別に, トレーニング前後の平 均值を, paired t- testにて比較した。

分析には, SPSS6.1を使用し, 有意水準を 5\%とした。

\section{IV. 結 果}

表 1 に，対象者の身体所見を示す。トレーニング群と コントロール群の身体所見には，いずれも有意差は認め られなかった。また, トレーニング前後の体重, 体脂肪 率は, 2 群とも有意差はなかった。

表 2 に, 膝伸展筋群・屈曲筋群の\%BWを示す。トレー ニング群の膝屈曲 $0 \mathrm{deg} / \mathrm{s}$ を除く, すべての\%BWに変化 は認められず, 筋力に変化はなかった。。

表3に, 歩行能力の結果を示す。トレーニング群では, 最大歩行速度と歩行率がトレーニング後の方が有意に増 加したが，歩幅には有意な変化は認められなかった。コ ントロール群では，トレーニング前後で，いずれも変化 は認められなかった。6MD は, トレーニング群，コント ロール群ともに, トレーニング後の方が増加した。

表4に, 重心動摇距離・面積を示す。トレーニング群, コントロール群ともに, 重心動摇に変化は認められな かった。

表5に, FBSの得点とFRを示す。トレーニング群では, FBS, FR ともに, トレーニング後の方が向上していた。 コントロール群では, いずれも変化は認められなかった。

\section{V. 考 察}

これまで, 中高年者を対象に施設や運動機器を利用し てトレーニングを施行した研究は多い4-6,9,12)が, 家庭で のトレーニングを施行した報告は少ない。また，これら の報告では, 対象者を活動レベルの低い者としている場 合が多く, 日常生活や歩行に問題のない, 健常者の身体 機能に与えるトレーニング効果も明らかではない。

本研究結果では, 膝屈伸筋力は, トレーニング前後で 
表 1 対象者の身体所見（平均値士標準偏差）

\begin{tabular}{|c|c|c|c|c|c|c|}
\hline & \multicolumn{3}{|c|}{ トレーニング群（N=10） } & \multicolumn{3}{|c|}{ コントロール群 $(\mathrm{N}=7)$} \\
\hline & 前 & 後 & $\mathrm{p}$ 值 & 前 & 後 & $\mathrm{p}$ 値 \\
\hline 年 齢 （歳） & $68.8 \pm 4.1$ & & & $69.0 \pm 3.7$ & & \\
\hline 身 長 $(\mathrm{cm})$ & $149.2 \pm 2.8$ & & & $149.1 \pm 6.6$ & & \\
\hline 体 重（kg） & $52.1 \pm 7.7$ & $51.9 \pm 7.7$ & n.s. & $51.6 \pm 7.8$ & $50.8 \pm 7.0$ & n.s. \\
\hline 体脂肪率 (\%) & $27.6 \pm 4.0$ & $26.8 \pm 4.5$ & n.s. & $26.6 \pm 3.6$ & $25.7 \pm 2.7$ & n.s. \\
\hline
\end{tabular}

n.s. : not significant

表 2 トレーニング前後の膝屈伸筋群の \% BW(ピークトルク值 $(\mathrm{Nm}) /$ 体重 $(\mathrm{kg}) \times 100 \times($ 平均值士標 準偏差)

\begin{tabular}{|c|c|c|c|c|c|c|c|}
\hline & \multirow[b]{2}{*}{$\mathrm{deg} / \mathrm{s}$} & \multicolumn{3}{|c|}{ トレーニング群 $(\mathrm{N}=10)$} & \multicolumn{3}{|c|}{ コントロール群 $(\mathrm{N}=7)$} \\
\hline & & 前 & 後 & $\mathrm{p}$ 值 & 前 & 後 & $\mathrm{p}$ 值 \\
\hline \multirow[t]{3}{*}{ 膝伸展 } & 0 & $184.2 \pm 29.0$ & $191.3 \pm 30.5$ & n.s. & $199.1 \pm 49.3$ & $209.1 \pm 36.2$ & n.s. \\
\hline & 60 & $137.4 \pm 22.9$ & $140.6 \pm 14.7$ & n.s. & $152.4 \pm 29.5$ & $165.1 \pm 19.3$ & n.s. \\
\hline & 180 & $87.3 \pm 11.2$ & $87.2 \pm 7.2$ & n.s. & $101.9 \pm 17.0$ & $105.6 \pm 13.9$ & n.s. \\
\hline \multirow[t]{3}{*}{ 膝屈曲 } & 0 & $66.7 \pm 15.8$ & $66.0 \pm 14.5$ & $<0.05$ & $75.2 \pm 25.6$ & $73.3 \pm 24.3$ & n.s. \\
\hline & 60 & $75.7 \pm 16.9$ & $80.1 \pm 13.0$ & n.s. & $83.9 \pm 24.6$ & $84.1 \pm 16.7$ & n.s. \\
\hline & 180 & $57.3 \pm 10.1$ & $59.1 \pm 10.0$ & n.s. & $60.8 \pm 16.0$ & $60.6 \pm 9.8$ & n.s. \\
\hline
\end{tabular}

n.s. : not significant

表 3 トレーニング前後の歩行能力（最大歩行速度, 歩幅, 歩行率, 6MD） (平均值士標準偏差)

\begin{tabular}{|c|c|c|c|c|c|c|}
\hline & \multicolumn{3}{|c|}{ トレーニング群（N=12） } & \multicolumn{3}{|c|}{ コントロール群 $(\mathrm{N}=7)$} \\
\hline & 前 & 後 & $\mathrm{p}$ 值 & 前 & 後 & $\mathrm{p}$ 值 \\
\hline 最大歩行速度（m/s） & $1.9 \pm 0.2$ & $2.0 \pm 0.4$ & $<0.01$ & $2.1 \pm 0.3$ & $2.1 \pm 0.3$ & n.s. \\
\hline 歩 幅 (m) & $0.7 \pm 0.04$ & $0.7 \pm 0.06$ & n.s. & $0.7 \pm 0.06$ & $0.7 \pm 0.08$ & n.s. \\
\hline 歩行率（step/min） & $158.0 \pm 14.9$ & $183.2 \pm 19.4$ & $<0.01$ & $163.6 \pm 25.5$ & $173.3 \pm 26.5$ & n.s. \\
\hline $6 \mathrm{MD}(\mathrm{m})$ & $441.2 \pm 62.0$ & $546.2 \pm 53.9$ & $<0.01$ & $470.5 \pm 93.8$ & $527.5 \pm 45.4$ & $<0.05$ \\
\hline
\end{tabular}

n.s. : not significant

表 4 トレーニング前後の重心動摇（平均値士標準偏差）

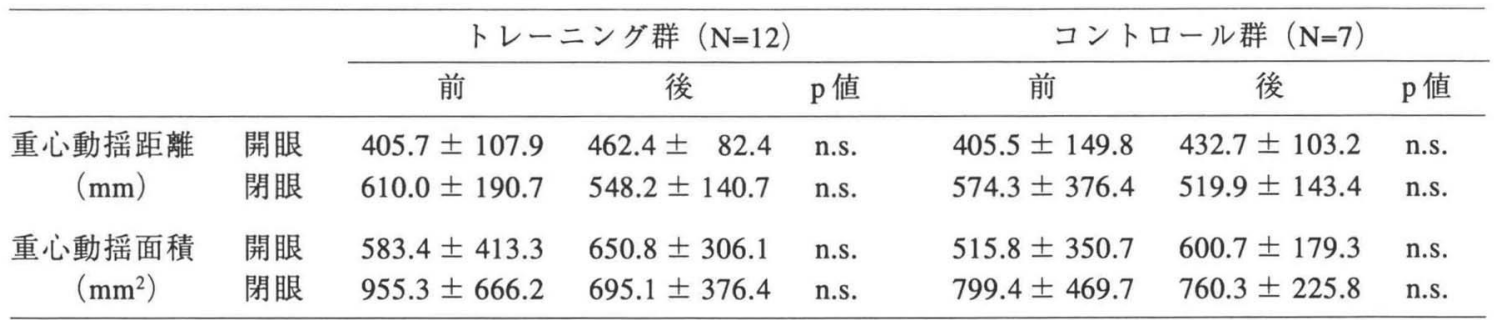

n.s. : not significant

表 5 トレーニング前後の Functional Balance Scal, FR（平均值士標準偏差）

\begin{tabular}{|c|c|c|c|c|c|c|}
\hline & \multicolumn{3}{|c|}{ トレーニング群（N=12） } & \multicolumn{3}{|c|}{ コントロール群 $(\mathrm{N}=7)$} \\
\hline & 前 & 後 & $\mathrm{p}$ 值 & 前 & 後 & $\mathrm{p}$ 值 \\
\hline FBS & $55.7 \pm 0.5$ & $56.0 \pm 0.0$ & $<0.05$ & $55.7 \pm 0.5$ & $55.9 \pm 0.5$ & n.s. \\
\hline FR & $0.18 \pm 0.03$ & $0.21 \pm 0.03$ & $<0.01$ & $0.20 \pm 0.03$ & $0.21 \pm 0.03$ & n.s. \\
\hline
\end{tabular}

FR : Functional Reach $(\mathrm{cm}) /$ 身長 $(\mathrm{cm})$, n.s. : not significant 
有意な変化はなかった。

筋力增強訓練の効果について, Agre ら ${ }^{12)} は, 63 \sim 88$ 歳女性を対象に，重錘バンドを使用した低負荷の抵抗運 動と有酸素運動を行い，筋力増強を認めている。彼らの 報告によると，運動頻度は1回1時間，1週間に3日間で, 25 週間行っている。運動強度は, 最大心拍数の $65 \%$ を目 標心拍数としている。また, Sauvage ら5)は, 施設に入所 している高齢男性を対象とし，筋力増強訓練と自転車工 ルゴメータによる有酸素運動を行った結果，筋力，持久 力，歩行能力の改善を報告した。彼らの報告では，運動 頻度を 1 週間に 3 日間，12週間行っている。運動強度は, 有酸素運動では最大心拍数の $70 \%$ 以上を目標心拍数に設 定し, 筋力増強訓練では最大筋力の $40 \sim 60 \%$ の負荷で 行っている。本研究での運動強度は, 1項目の運動を8 10 回行った時の RPEを 15 とし, 運動頻度は 1 日 3 セッ 卜，1週間に2 3 日とした。本研究では特定の有酸素運 動は設定しておらず，Agreらや Sauvage らの研究とは運 動内容や強度，頻度が異なる点がある。

また, 対象者の条件について Sauvageらは, 年齢 70 歳 以上, 徒手筋力検查で膝屈伸筋力は 5 未満, 歩行補助具 の使用なしに $8 \mathrm{~m}$ 歩行可能のように, 比較的低い活動性 の者としている。本研究の対象者は, 平均年齢69歳前後 であった。また，結果には示していないが，健康に対す る興味があり, 日常生活の移動を, 意識的に歩行か自転 車で行っている者が多かった。また，運動習慣のある者 も多く, 本研究の対象者は比較的活動レベルが高かった と言えるだろう。家庭でのトレーニングであったこと， 対象者の年齢や身体機能の違いが，このような結果と なったと考えられる。

バランス能力について, 本研究結果では, トレーニン グ群のFBSとFRに有意な向上が認められた。しかし，重 心動摇に変化はなかった。FBSが向上した 4 名のうち, 1 名は夕ンデム立位，3名がFRの向上であった。FBSのよ うな機能的バランス能力は, 体性感覚や前庭系だけでな く，より筋力の影響を受ける。タンデム立位では，下肢 の近位部の筋活動がより要求され, FRでは, 下肢の遠位 部の筋活動がより要求される。本研究では, 膝屈伸筋力 のみの測定であるため, 他の下肢筋群の筋力については 不明である。しかし，本研究で行ったトレーニングには， 膝屈伸以外の運動も含まれており，また，立位での下肢 のトレーニングでは, 運動を行っていない側は支持脚と なり，支持脚としてトレーニングされていることとなる。 このことから, 膝屈伸筋群以外の筋群に, 筋力増強効果
が得られたとも考えられる。

歩行能力について, 本研究結果では, トレーニング群 の最大歩行速度，歩行率に有意な増加が認められた。 Judge ら ${ }^{4)}$ は, 高齢男女の歩行速度の改善を目的に, ス卜 レッチや筋力増強訓練，バランス訓練を 12 週間行い, 歩 行速度や歩幅の改善と,下肢筋力の増強を報告した。こ の報告では，下肢筋力と，通常行っている歩行速度との 有意な相関を認めている。加齢に伴う最大歩行速度の低 下は，筋力や神経系，下肢関節の柔軟性の低下とそれら の相互作用によるものである。また，通常行っている歩 行速度の低下は歩幅の減少であり, 最大歩行速度の低下 は歩行率の低下であると言われている4)。加齢に伴う歩 行周期の変化について伊東ら $\left.{ }^{13}\right)$ は, 最大歩行速度の低下 は歩幅と歩行率によるものであり, 歩幅には筋力が, 歩 行率にはリズム運動とバランス機能が関与していると述

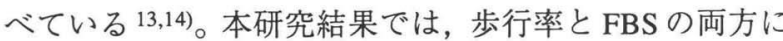
向上が認められ，筋力と歩幅には変化は認められなかっ た。これは，伊東らの報告と一致する結果であった。6MD は，トレーニング群，コントロール群ともに増加した。2 群における6MDの増加の理由としては, 測定に対する慣 れを考慮する必要がある。一般に，健康維持や疾病予防 を目的とした運動強度は，最大酸素摂取量の $40 \sim 60 \%$ を 目標心拍数とし, RPE12 16の負荷が効果的であると言 われている15)。本研究においても運動強度をRPE15とし たが，持久力に重要となる心肺機能の向上は，本研究結 果から確認することはできなかった。

これまでの報告におけるトレーニングは，運動内容・ 強度・頻度の点から, 施設や運動機器を利用することや, 理学療法士の指導下でなければ長期の継続は困難である と考えられる。本研究におけるトレーニングは家庭で行 うため，個人のトレーニングに対するモチベーションが 重要となる。そのため, 運動機器を利用したり, 専門家 が介入したトレーニングに比較して，トレーニング効果 は現れにくいと推測された。本研究で行ったトレーニン グは, 顕著な筋力増強効果はなかったが, 機能的バラン ス能力と歩行速度に向上をもたらした。

本研究の今後の課題は, 今回の対象者よりも低い活動 性の対象者における, 筋力, バランス能力, 移動能力へ のトレーニング効果を検討することである。また，今回 の対象者のような地域の健常中高年者については, 筋力 増強に効果のあるトレーニング方法の検討が必要である。 


\section{参考文献}

1) 荒尾 孝:老化予防. 総合リハ, $25: 805-809,1997$.

2) Frontera WR, et al.: A Cross-sectional Study of Muscle Strength and Mass in 45- to 78-yr-old Men and Women. J Appl Physiol, 71: 644-650, 1991.

3) Bendall MJ, et al.: Factors Affecting Walking Speed of Elderly People. Age Ageing, 18: 327-332, 1989.

4) Judge JO, et al.: Exercise to Improve Gait Velocity in Older Persons. Arch Phys Med Rehabil, 74: 400-406, 1993.

5) Sauvage LR, et al.: A Clinical Trial of Strengthening and Aerobic Exercise to Improve Gait and Balance in Elderly Male Nursing Home Residents. Am J Phys Med Rehabil, 71: 333-342, 1992.

6) Chandler JM, et al.: Is Lower Extremity Strength Gain Associated with Improvement in Physical Performance and Disability in Frail, Community-Dwelling Elders? Arch Phys Med Rehabil, 79: 24-30, 1998.

7) Berg KO, et al.: Measuring balance in the elderly: preliminary development of an instrument. Physiother Can, 41: 304-311, 1989.

8) Berg KO, et al.: Clinical and Laboratory Measures of Postural
Balance in an Elderly Population. Arch Phys Med Rehabil, 73: 1073-1080, 1992.

9) Shumway-Cook A, et al.: The Effect of Multidimensional Exercises on Balance, Mobility, and Fall Risk in CommunityDwelling Older Adults. Phys Ther, 77: 46-57, 1997.

10) Berg KO, et al.: The Balance Scale: Reliability Assessment with Elderly Residents and Patients with an Acute Stroke. Scand J Rehab Med, 27: 27-36, 1995.

11) 青木 信夫·他 (監訳): お年寄りのための安全な筋力トレー ニング. 保健同人社, 1992.

12) Agre JC, et al.: Light Resistance and Stretching Exercise in Elderly Women: Effect Upon Strength. Arch Phys Med Rehabil, 69: 273-276, 1988.

13) 伊東 元・他: 健常男子の最大速度歩行時における歩行周期 の加齢変化. 日本老年医学会雑誌, $26: 347-351,1989$.

14) 伊東 元·他: 健常老年者における最大歩行速度の決定因一 重心動摇と歩行率の関連一. 理学療法学, 17:123-125, 1990.

15) アメリカスポーツ医学協会 (編): 運動処方の指針 (原著第 4 版). 南江堂, 1993, pp93-112. 